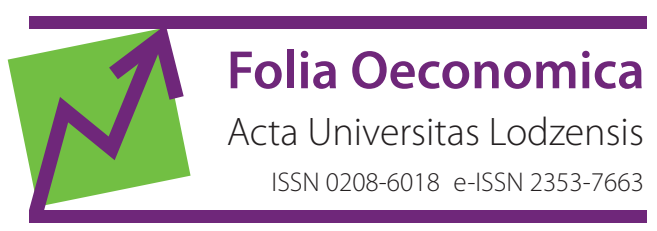

www.czasopisma.uni.lodz.pl/foe/

2(328) 2017

DOI: http://dx.doi.org/10.18778/0208-6018.328.02

\title{
Tomasz Sosnowski
}

University of Lodz, Faculty of Economics and Sociology,

Department of Business Analysis and Strategy, tomasz.sosnowski@uni.lodz.pl

\section{Corporate Governance and the Time to Full Exit in the Private Equity Divestment Process on Warsaw Stock Exchange}

\begin{abstract}
This paper investigates empirically the links between the specific solutions of corporate governance in portfolio companies of private equity funds and the duration of divestment process after the first listing of company's shares on the stock market. Using a sample of 41 IPOs from Warsaw Stock Exchange between 2005 and 2015 I find that the pre-IPO set up corporate governance significantly affects the time of the private equity funds' full exits. I find evidence that the higher share of private equity funds in the total number of votes at the general meeting of the company's shareholders before the IPO negatively impacts the chance of the full exit occurrence. However, the data reveal that the syndication and previous experience of private equity fund in IPO exits are important factors affecting the probability of the investment's end.
\end{abstract}

Keywords: divestment, initial public offering, IPO, private equity, full exit

JEL: G11; G24; G32 


\section{Introduction}

The activity of private equity funds is geared towards multiplying the value of the capital entrusted in the management by the investors for a predetermined period of time (Cumming, Johan, 2009: 3-5). This goal is achieved through the allocation of funds and managerial competencies into non-public companies characterized by the significant potential of the market value growth, the specific tools of the Schumpeterian creative destruction (Panfil, 2009: 169). In return for this support the private equity fund usually becomes a part owner of the company and the expected measurable effect of the investment is the increase of the market value of shares held in the portfolio company (Sobańska, Sieradzan, 2004: 13; Panfil, 2005: 19; Wrzesiński, 2008: 23).

The support for the development of enterprises occurs not only with the inflow of capital but private equity funds generally actively participate in the building of the market value (Barry et al., 1990: 447-471; Bascha, Walz, 2001: 286). They engage in the company by the strategic advice and operational management (Panfil, 2005: 109; Ortgiese, 2007: 47; Pietraszewski, 2007: 146). Individual companies are also included in the extensive business network of fund's portfolio companies, creating a kind of private equity keiretsu (Lindsey, 2002:1-46; Hsu, 2004: 1805-1844; Hochberg, Ljungqvist, 2007: 251-301).

However, the success of the investment occurs only when the private equity fund holdings will be sold and the potential capital gain will be converted into cash. Thus, the specific nature of this specialized group of investors causes the exit strategy from investment to largely determine the possibility of achieving a particular return on investment.

IPO as a method of divestment also faces a great interest of researchers. A great amount of research on the disinvestment processes of private equity funds were mainly focused on seeking for answers to two key research questions: a) what factors influence the private equity fund's choice of time and divestment method (Cumming, 2008: 1947-1982; Cockburn, MacGarvie, 2009: 729-773; Bienz, Walz, 2010: 1071-1116; Puri, Zarutskie, 2012: 2247-2293) and b) how private equity funds affect the market value of the portfolio companies in the short and long term (Brav, Gompers, 1997: 1791-1821; Krishnan et al., 2011: 1295-1333; Liu, Ritter, 2011: 579-601). Most papers treat the first listing of the portfolio company's shares on the stock exchange as the definitive end point of private equity fund investment and the accomplishment of the expected capital gain (Paeglis, Veeren, 2013: 106). However, research on the private equity funds' practice of reducing the capital commitment in portfolio companies show that IPO generally only starts the divestment process (Cumming, MacIntosh, 2003a: 512; Gompers, Lerner, 2006: 423; Povaly, 2007: 252; Wrzesiński, 2008: 231; Paeglis, Veeren, 2013: 104-123) and the full exit from the investment may occur even after many years (Lin, Smith, 1998: 241-263). 
The main aim of the study is to evaluate the relationship between the adoption of specific solutions of corporate governance in portfolio companies of private equity funds and the time elapsing from the first listing of company's shares on the stock market to the full exit of the private equity fund from the investment.

Conducting a research which fits in the cognitive gap existing in the literature is extremely important from the perspective of the private equity funds' business activity. Bearing in mind the results of studies indicating an overvaluation of shares of new stock companies in the long term (Loughran, Ritter, 1995: 23-51; Ritter, 1991: 3-27; Brav et al., 2000: 209-249; Schuster, 2003: 1-39; Siwek, 2005: 59; Zheng, 2007: 287-309) it should be noted that the excessive extension of time to the full exit from the fund investment may indeed increase the risk forthe whole investment process and negatively affect its return. Moreover, this situation creates the implicit cost of inefficiently deployed unique and limited resources of a private equity fund (Neus, Walz, 2005: 254).The financial capital and the skills of private equity fund managers located in the uncompleted investment could be used to develop new, potentially highly profitable projects (Paeglis, Veeren, 2013: 104).

In order to achieve the goal of the research the main hypothesis has been formulated and it states that the use of certain formal and informal corporate governance arrangements before IPO has a significant impact on the duration of the private equity fund divestment process.

\section{Some mechanisms of corporate governance in the disinvestment process of private equity funds}

A specific feature of private equity funds investments is the diversity of forms and methods of their actions. It is pointed out that one of the main sources of growth in the value of portfolio companies are favourable changes in corporate governance following the private equity fund investment (Masulis, Thomas, 2009: 227), which allow for the reduction of agency costs through the most efficient use of the resources involved in the company. At the time of investment private equity funds negotiate complex control rights and introduce extensive monitoring and advisory systems (Kaplan, Stromberg, 2003: 281-316; Kaplan et al., 2007: 273-311). However, as a result of the IPO a number of changes in the ownership structure of the portfolio company occurs, which affects the ability of individual shareholders to establish and enforce specific corporate governance solutions. The start of the reduction process of the private equity fund capital commitment in the portfolio company by the going public results in the loss of its privileged position and reduces the scale of corporate governance over the company. The private equity fund has incentives to ensure that optimal governance systems are in place in their portfolio 
companies at the time the company goes public in order to ensure the preservation of the value of their investment until their positions have been unwound and their profits booked (Hochberg, 2012: 430).

The results of the research conducted on many markets indicate that the strategy of partial exit is mainly used in the divestment process by IPO (Barry et al., 1990: 447-471), which involves a gradual sale of all private equity fund's holdings after IPO (Cumming, MacIntosh, 2003b: 514). Private equity funds typically commit themselves not to sell their shares on stock exchange by the specified time after the IPO. The lock up is established in order to signal to the investors the favourable growth prospects of the company's market value in the future (Brav, Gompers, 2003: 1-29; Arthus et al., 2009: 360-372). However, in many cases, one can notice that after this period the private equity fund still remains a significant shareholder in a listed company.

The time extension of the private equity fund's investment process after IPO can be caused by many factors. Some studies highlight the importance of market conditions for the length of the period in which a full exit is achieved. It is expected that the likelihood of full exit increases in hot market periods (Cumming, MacIntosh, 2003b: 538-544) and the private equity fund's holding periods after first listing of company's shares on the stock exchange are significantly shorter during bull market (Fürth, Rauch, 2015: 828). A growing number of studies draw attention to the importance of the factors directly related to the main actors of the private equity investment process. Cumming \& MacIntosh link the use of the partial exit strategy with the problem of information asymmetry between the existing and new shareholders of the portfolio company (Cumming, MacIntosh, 2001: 452) and the negative impact of the information gap on the valuation of the market value of the company (Cumming, MacIntosh, 2003a: 103-104). This problem arises especially in the stock market. When the disinvestment process starts, the level of the information gap is relatively large, but later the market obtains new information and the gap is reduced over time (Neus, Walz, 2005: 254). In addition, if the private equity fund remains the shareholder of the company after IPO and acts as the investor possessing an information advantage through long-term cooperation, it certifies the growth potential of the company's market value in the future and limits the adverse consequences of the information asymmetry (Megginson, Weiss, 1991: 879-903). Paeglis \& Veeren indicate that the length of the period to the full divestment is related to the ownership structure of the portfolio company (Paeglis, Veeren, 2013: 104-123). The results of their empirical research conducted on US companies show that private equity funds exit firms with intermediate levels of initial founder ownership faster than those with either low or high levels of ownership. Schmidt \& Bock analyse the issue of partial and full exit through IPO from the prospect theory and behavioural finance point of view and suggest that the specific features of a private equity fund and its dynamics 
significantly affects the pace of the divestment strategy (Schmidt, Bock, 2015: 6882). Their findings indicate that in the case of first-time, reputation lacking funds the delay in the full exit is expected, while private equity funds satisfied with the achieved financial results opt for a faster divestment.

The growing body of literature also points to the importance of one of the informal institutions of the corporate governance for the private equity funds divestment duration, namely: reputation. The way in which a fund is perceived by the market and the assessment of its actions is a very important factor that influences the economic success in the private equity market (Hsu, 2004: 1805-1844; Nahata, 2008: 127-151). Private equity funds are set up on the predefined limited period of time. In order to establish new funds and raise additional capital fund managers must prove that they are able to successfully build the value of the portfolio companies and effectively manage the entrusted resources. A good reputation allows the fund to attract new investors, facilitate cooperation with other funds during certain projects, as well as use it in the process of acquiring new firms to the investment portfolio (Black, Gilson, 1998: 254). Considering the importance of reputation for the disinvestment process Lin \& Smith noted that funds with an established position in the market, which accumulated the appropriate reputational capital, decide to sell their holdings in the portfolio company shortly after its first listing on the stock exchange (Lin, Smith, 1998: 241-263). Furthermore, according to the model presented by Neus \& Walz, the experienced private equity funds with a high market share build up reputation disinvest early and are able to sell even their high-quality ventures at close to their true value (Neus, Walz, 2005: 253-277), without any need for additional costs in the form of underpricing, as in the case of funds operating in the market for a relatively short time (Gompers, 1996: 133-156). Moreover, Krishnan et al. point out that the reputation of a private equity fund is positively related to the efficiency and the value of the company after its IPO. Their studies indicate that in the divestment processes of more reputable funds the likelihood that they remain a shareholder of the company up to three years after the IPO increases and these funds exhibit more active post-IPO involvement in the corporate governance of their portfolio companies (Krishnan et al., 2011: 1295-1333).

Many of the key decisions relating to the specific strategy of divestment are made before the company goes public and to the model of corporate governance corresponding to this period. In this context it is extremely important to seek for answers to the question about the existence of any links between the pre-IPO system of corporate governance in the portfolio companies and the processes of the reduction of capital commitment of private equity funds in these companies. 


\section{The sample and methodology of empirical research}

The empirical studies have been carried out on a sample of private equity funds' portfolio companies whose shares were listed on the main market of the Warsaw Stock Exchange because of the divestment process through IPO for the first time between 2005 and 2015. The study takes into account only those companies whose head office was located in Poland and their IPO was connected with the sale of primary or secondary shares. The dataset includes information about 41 new listed companies.

The principal research method used in the study is the survival analysis. Although this technique has been developed in biological and medical science, it can be successfully applied in the analysis of issues in finance (Rossa, 2005: 6).

Survival analysis includes a set of statistical procedures for which the examined variable is the moment of occurrence of a specific event (Collet, 2003: 1). The subject of research in the survival analysis is the duration of time to the particular event (Rossa, 2005: 6), that is the time elapsed since the start of observation until a specific event happens, which clearly ends the observation of a certain case (eg. in medicine the patient's death). In this paper the subject of the study is the time from the first listing of portfolio company on the Warsaw Stock Exchange to the sale of all its shares owned by a private equity fund ${ }^{1}$. What is important, this method allows for the determining of the connection of studied factors to the end point, even if the information regarding the occurrence of the event for some observations is limited (Fendler et al., 2011: 90), that is in the presence of censored data. This issue is particularly important in the study of private equity fund's exits made through IPO, as it enables to examine the transactions in which the divestment process is not yet completed.

In the first stage of studies of the divestment process on the stock exchange the survival function $S(t)$ was used, which gives the probability that the analysed economic process will take longer than the specified time $t$ (Klein, Moeschberger, 1997: 23). The Kaplan-Meier estimate has been used and the nonparametric maximum likelihood estimate of $S(t)$ is calculated by the formula given below (Stevenson, 2009: 7):

$$
\hat{S}(t)=\prod_{t_{i} \leq t}\left(1-\frac{d_{i}}{r_{i}}\right),
$$

where:

$d_{i}$ - the number of events at the time $t_{i}$, $r_{i}-$ the number of objects at risk.

${ }^{1}$ Due to the availability of information it is assumed that the full exit from investment occurs when the share of private equity fund in shareholding structure drops below $5 \%$. The information reflects the situation on 31 December 2015. 
Next, to identify the factors affecting the duration of the divestment process the semi-parametric Cox-proportional hazard method has been used, in which the modelling event is defined as a full exit of private equity fund from the investment. Hazard function $h_{i}(t)$, represents the probability that an individual will experience an event in an infinitesimal period of time, assuming that the event has not occurred up to the beginning of the interval for $i$-object (Balicki, 2006: 30-34) and can be estimated as follows (Collet, 2003: 59-60):

$$
\begin{gathered}
h_{i}(t)=f\left(x_{i}\right) h_{0}(t) \\
f\left(x_{i}\right)=e^{\eta_{i}} \\
\eta_{i}=\beta_{1} x_{1 i}+\beta_{2} x_{2 i}+\ldots+\beta_{n} x_{n i} \\
h_{i}(t)=e^{\beta_{1} x_{i i}+\beta_{2} x_{2 i}+\ldots+\beta_{n} x_{n i}} h_{0}(t)
\end{gathered}
$$

The underlying hazard function $h_{0}(t)$ corresponds to the probability of occurrence of an event if the values of all explanatory variables are zero and $f\left(x_{i}\right)$ is a function of a vector of explanatory variables for the $i$-object. It is assumed that the probability of an occurrence of a particular event depends on the value of $n$ explanatory variables: $X_{1}, X_{2}, \ldots, X_{n}$. The values of the explanatory variables form vector $x$ such that $x=\left(x_{1}, x_{2}, \ldots, x_{n}\right)$, where $x_{1}, x_{2}, \ldots, x_{n}$ are the values of the explanatory variables (Zaremba-Pechmann, 2010: 124). The regression coefficients $\beta_{i}$ assigned to the appropriate variable represent the individual contribution of each factor to the hazard which is a resultant effect of the presence or absence of the individual components of the model (Fendler et al., 2011: 97).

In the empirical studies on the dynamics of private equity funds divestments, carried out on stock exchange, certain characteristics of corporate governance of surveyedcompanies are used as explanatory variables (see Tab. 1).

The first group of explanatory variables represents the characteristics relating to the formal institutions of corporate governance and the role played by the private equity funds in the supervisory activities over portfolio companies. Variables $G M_{P E}$ and $S B_{P E}$ directly correspond to the share of private equity funds at the general meeting of shareholders and the supervisory board of the company, respectively. The second group of variables represents characteristics that refers to the reputation as an institution of corporate governance. The calculation of the amount of reputational capital of private equity funds on Polish market is a difficult and problematic issue, because its direct measurement is not possible. Accepting arguments of $\mathrm{Kr}$ ishnan et al. (Krishnan et al., 2011: 1295-1333) the basic measure of reputational capital is the share of market value of IPOs backed by the private equity fund in the value of all IPOs in the sample in the preceding three calendar years (IPO Market Share). The value of individual IPOs are gross proceeds and they have been calculated using the offer price. The next variable in this group refers to the issue of syn- 
dication on private equity market. SYNDICATION is a dummy variable showing the presence of more than one private equity fund in the shareholding structure of the portfolio company at the time of the IPO. The increasing number of private equity investors, as market players having a certain reputation in the market, may affect the total amount of accumulated reputational capital. In addition, SIZE as a control variable is used. It relates to the size of the company and refers indirectly to the problem of information asymmetry in the IPO process (Cormier et al., 2010: 580), as well as the potential demand restraints in the stock market.

Table 1. Description of explanatory variables

\begin{tabular}{|l|l|}
\hline \multicolumn{1}{|c|}{ Variable } & \multicolumn{1}{c|}{ Description } \\
\hline$G M_{P E}$ & $\begin{array}{l}\text { The pre-IPO share of private equity funds in the total number of votes at the } \\
\text { general meeting of the portfolio company } \\
\text { shareholders. }\end{array}$ \\
\hline$S B_{P E}$ & $\begin{array}{l}\text { The share of private equity funds in the supervisory board of the portfolio } \\
\text { company prior to the IPO. }\end{array}$ \\
\hline $\begin{array}{l}\text { IPO Market } \\
\text { Share }\end{array}$ & $\begin{array}{l}\text { The share of market value (gross proceeds) of IPOs backed by the specific } \\
\text { private equity fund in the value of all IPOs in the sample in the preceding } \\
\text { three calendar years. }\end{array}$ \\
\hline SYNDICATION & $\begin{array}{l}\text { A dummy variable that takes the value 1 when more than one private equity } \\
\text { fund is a shareholder of the portfolio company at the time of the IPO, and } 0 \\
\text { otherwise. }\end{array}$ \\
\hline SIZE & $\begin{array}{l}\text { Capitalization of the company at the end of the first day of trading on the } \\
\text { Warsaw Stock Exchange (million PLN) }\end{array}$ \\
\hline
\end{tabular}

Source: author's own study

The information on the private equity fund's shareholdings, the number of funds and their participation in the supervisory bodies of the portfolio companies are hand-collected from analysed companies' prospectuses and current reports available in the ESPI system. The capitalization is taken from the Emerging Market Information Systems database. The source of information about the value of each IPO on the Warsaw Stock Exchange is http://gpwinfostrefa.pl.

\section{Empirical analysis and results}

On the basis of information regarding the participation in the general meeting of shareholders it can be stated that before the IPO on the Warsaw Stock Exchange the blocks of shares corresponding to a significant proportion of company's share capital were in the investment portfolios of private equity funds. The data presented in Figure 1 shows that in the period preceding the firm's IPO in more than half of the surveyed companies (median) at least $61.2 \%$ of the votes belonged to private equity funds (see Fig. 1 and Tab. 2). 


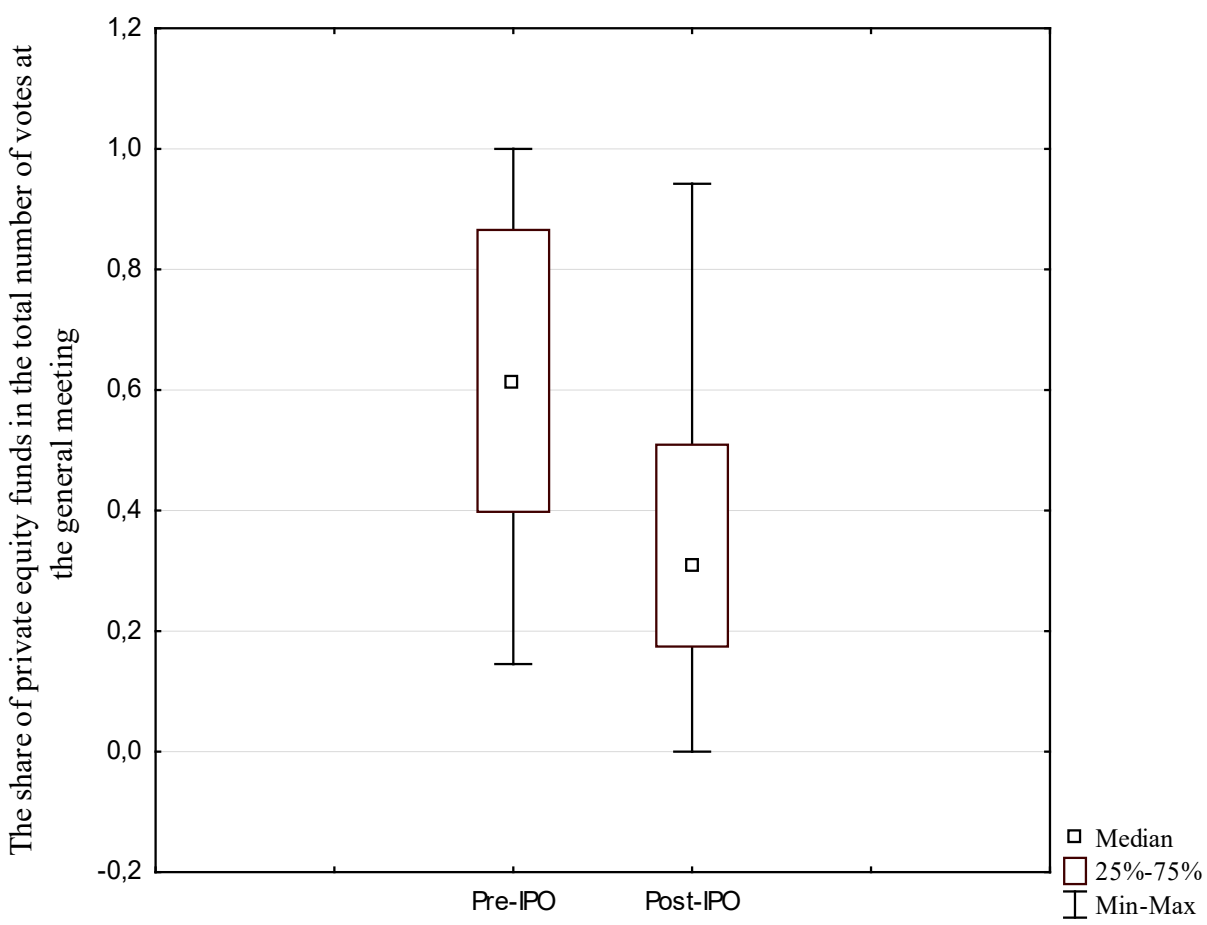

The non-parametric Wilcoxon rank-sum test: $Z=5.5109 ;$-value $<0.0000$

Figure 1. The share of private equity funds in the total number of votes at the general meeting of portfolio company's shareholders before and after first listing on the Warsaw Stock Exchange

Source: the author's own study based on prospectuses and current reports of companies

As a consequence of IPO the capital commitment of private equity funds in the portfolio companies has been significantly reduced. The median of the private equity funds' share in the total number of votes at the general meeting of company's shareholders has halved and reached the level of $30.6 \%$.

Empirical research on the practice of the divestments processes of private equity funds performed on the Warsaw Stock Exchange indicates that the reduction of their capital involvement in portfolio companies proceeds with diverse dynamics.

Based on the information presented in Figure 2 one can see that the probability of the duration of the private equity fund's investment to a specific point on the timeline (that is the probability of survival) decreases after the first listing of company's shares on the stock exchange at a relatively constant rate to approximately 3.5 years. The likelihood that a private equity fund remains a shareholder of the company thereafter stands at approximately $30 \%$. Then you can see a reduction 
in the dynamics of the survival function decline, which means that the full exit of private equity fund over time becomes less and less likely.

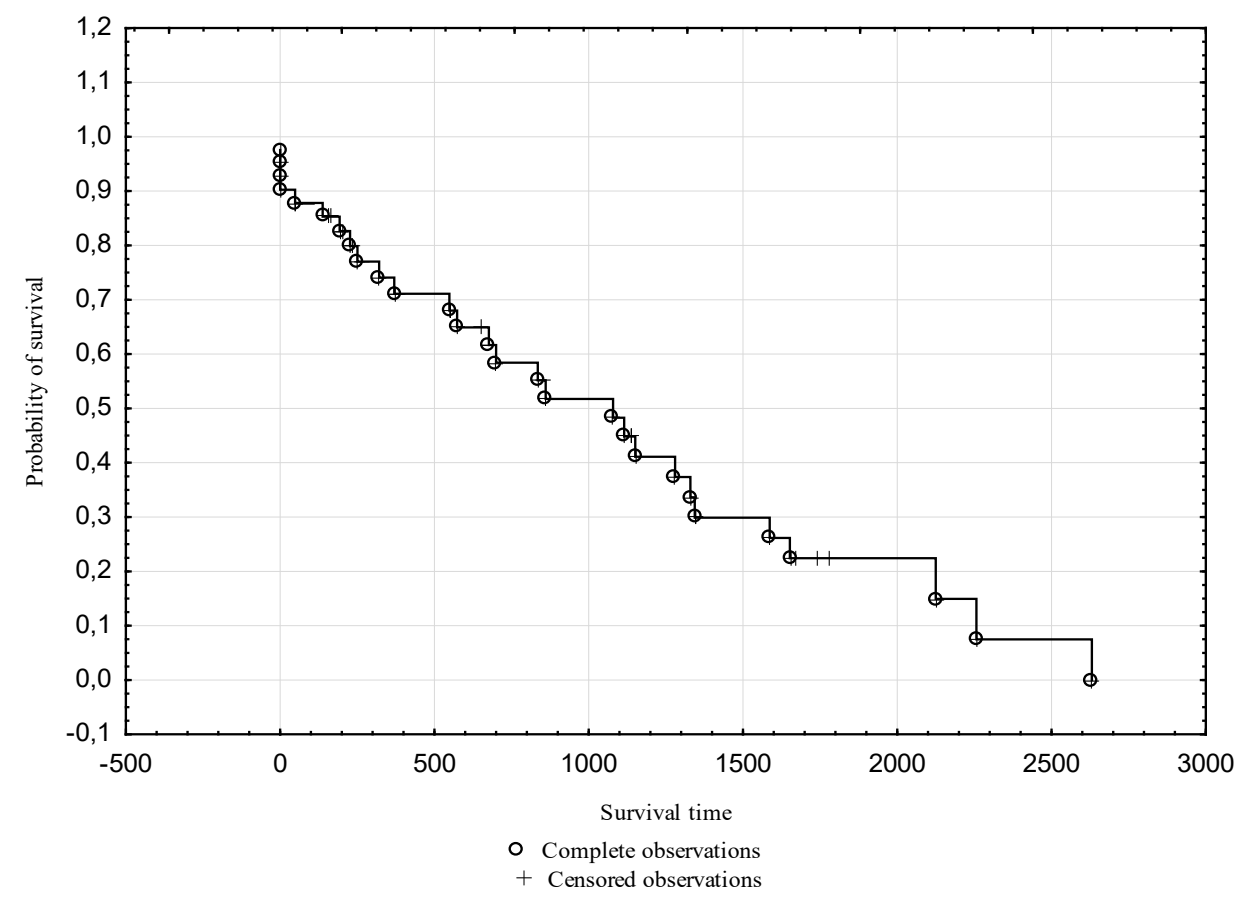

Figure 2. Survival function - Kaplan-Meier estimation

Source: the author's own study based on current reports of companies

The data in Table 2 indicate that, undoubtedly, private equity funds in their investment activities have a significant impact on the portfolio companies business and play a vital role in the corporate supervision. Before the IPO, the private equity funds have on average $61.21 \%$ of the votes at the general meeting of shareholders and their representatives are on average $48.25 \%$ of the supervisory board. In at least half of surveyed companies every second member of the supervisory board was appointed by a private equity fund (see Tab. 2).

Usually only one private equity fund is among the shareholders of the company. Syndication is observed in $24.39 \%$ of companies. In most cases private equity funds had not made any IPO divestment for three calendar years prior to the first listing of the portfolio company's shares on the stock exchange. In addition, one can also notice that the descriptive statistics of the variable SIZE indicate considerable differences in the size of the companies in which the process of disinvestment through the Warsaw Stock Exchange is performed. Their capitalization at the IPO reaches the level from18.0 to 915.8 PLN million (see Tab. 2). 
Table 2. Descriptive statistics of explanatory variables

\begin{tabular}{|l|c|c|c|c|c|}
\hline \multicolumn{1}{|c|}{ Specification } & $\boldsymbol{G M}_{P E}$ & $\boldsymbol{S B}_{P E}$ & SYNDICATION & IPO Market Share & SIZE \\
\hline Mean & 0.6121 & 0.4825 & 0.2439 & 0.1429 & 277.5 \\
\hline Median & 0.6120 & 0.5000 & 0.0000 & 0.0000 & 183.1 \\
\hline Standard deviation & 0.2802 & 0.2168 & 0.4348 & 0.2457 & 256.0 \\
\hline Minimum & 0.1453 & 0.0000 & 0.0000 & 0.0000 & 18.0 \\
\hline 1stquartile & 0.3980 & 0.4000 & 0.0000 & 0.0000 & 86.5 \\
\hline 3rdquartile & 0.8655 & 0.6000 & 0.0000 & 0.1862 & 429.1 \\
\hline Maximum & 1.0000 & 1.0000 & 1.0000 & 0.7464 & 915.8 \\
\hline
\end{tabular}

Source: the author's own study

Next, using the intensity function of the recurrent event process, the information concerning the individual companies' corporate governance has been used to assess the probability of achieving a full exit from the private equity fund's investment after its IPO. Estimating the Cox proportional hazard regression models, the backward elimination of variables has been run in the selection process of variables significantly affecting the likelihood of occurrence of the private equity fund's full exit (Asselain et al., 2010: 408). Initially, the model takes into account all the analysed characteristics of the corporate governance. Then, the variables having the smallest statistical significance were subsequently removed by excluding in each next step the variable with the highest $p$-value greater than the critical value and the model was re-estimated (see Tab. 3).

In the first estimated model, which takes into account all the considered characteristics of the corporate governance, two variables turn out to be not statistically significant at the level of $\mathrm{p}$-value $<0.05$. Then, based on the level of $\mathrm{p}$-value for individual predictors, the variables $S I Z E$ and $S B_{P E}$ have been sequentially eliminated. Among all the subsequent estimations the model III has the lowest value of the Schwarz-Bayesian information criterion $(S B C)$ and fits the empirical data the best, which indicates the value of $\chi^{2}$ statistic together with corresponding $p$-value.

The analysis of coefficients in Model 3 allows one to conclude that the corporate governance applied by private equity funds in the investment process can significantly affect the duration of the divestments carried out on the stock exchange. The results indicate that a higher share of private equity funds in the total number of votes at the general meeting of company's shareholders before the IPO negatively affects the probability of the full exit occurrence. On the one hand, this result may indicate that one should expect the divestment process extension in companies that require greater supervision and involvement of the fund. On the other hand, one should also take into account the fact that the value of the variable $G M_{P E}$ relates directly to the share of the private equity fund in the share capital of the compa- 
ny, and the obtained results might indicate the presence of certain demand restrictions in the sale of significant holdings by major shareholders of public companies on the Warsaw Stock Exchange. However, taking into account the significantly positive coefficient for the variable SYNDICATION, it can be seen that the chances of the full exit are increasing when among company's shareholders there are more than one private equity fund. This result may indirectly indicate that the problematic issue in the divestment process may be the high concentration of ownership in a group of private equity investors, instead of the sale of holdings corresponding to a significant part of the company.

Table 3. Results of the hazard function estimation for 3 Cox regression models using backward elimination - endogenous variable is the time between the company's first listing on the Warsaw

Stock Exchange and the full exit from the investment of private equity fund

\begin{tabular}{|c|c|c|c|c|c|c|}
\hline Specification & $\chi^{2}$ & $\begin{array}{l}\text { p-value } \\
\text { for } \chi^{2}\end{array}$ & Explanatory variable & $\beta_{t}$ & $\begin{array}{c}\text { Wald } \\
\text { statistic }\end{array}$ & $\begin{array}{c}p \text {-value } \\
\text { for } \beta\end{array}$ \\
\hline Model I & 11.4836 & 0.0426 & $G M_{P E}$ & -2.1439 & 4.5246 & 0.0334 \\
\hline$S B C$ & 159.3238 & & $S B_{P E}$ & -0.1963 & 0.0246 & 0.8753 \\
\hline \multirow[t]{3}{*}{$R^{2}$} & 0.3364 & & SYNDICATION & 1.2725 & 4.5958 & 0.0321 \\
\hline & & & IPO Market Share & 2.5603 & 7.8912 & 0.0050 \\
\hline & & & $\ln S I Z E$ & -0.0137 & 0.0028 & 0.9577 \\
\hline Model II & 11.4808 & 0.0217 & $G M_{P E}$ & -2.1548 & 4.7674 & 0.0290 \\
\hline$S B C$ & 155.9944 & & $S B_{P E}$ & -0.1630 & 0.0228 & 0.8801 \\
\hline \multirow[t]{2}{*}{$R^{2}$} & 0.3364 & & SYNDICATION & 1.2664 & 4.7352 & 0.0296 \\
\hline & & & IPO Market Share & 2.5485 & 8.3237 & 0.0039 \\
\hline Model III & 11.4579 & 0.0095 & $G M_{P E}$ & -2.1938 & 5.2840 & 0.0215 \\
\hline$S B C$ & 152.6850 & & SYNDICATION & 1.2298 & 5.4402 & 0.0197 \\
\hline$R^{2}$ & 0.3358 & & IPO Market Share & 2.5192 & 8.5529 & 0.0035 \\
\hline
\end{tabular}

Source: the author's own study

The results of empirical studies are also the basis for the conclusion on a significant role of one of the informal institutions of corporate governance, that is the reputation, for the shortening of the duration of the disinvestment process through IPO. The increase in the value of the variables relating to this aspect, namely $S Y N$ $D I C A T I O N$ and IPO Market Share, can positively influence the probability of the occurrence of the end point of private equity investment. 


\section{Conclusions}

Exits through IPO are implemented with a diverse dynamics and sometimes private equity funds need even several years after the first listing of the portfolio firm's shares on the stock market to sell their holdings. The results of empirical studies support the presumption made in the research hypothesis that the pre-IPO corporate governance in the portfolio companies significantly affects the duration of the divestment process of private equity funds.

Based on the analysis of 41 divestment transactions on the Warsaw Stock Exchange it can be concluded that a higher share of private equity funds in the total number of votes at the general meeting of shareholders of the company before the IPO moves away the moment of a full exit from the investment. Moreover, in the context of the obtained results, the positive role of the private equity fund's reputation for the reduction of the disinvestment process duration should be emphasised. Both the use of syndication and previous experience of private equity fund in IPO exits can be considered as important predictors of the probability of the investment end point occurrence.

The results presented in the paper indicate the need for the continuation of studies aimed at the identification of factors affecting the time and pace of the private equity funds' IPO exits and provide a starting point for taking further scientific research on the evaluation of the divestment process efficiency. The inspiring field for further research is the multifaceted analysis of the importance of reputational capital for the effective performance of the private equity funds divestment strategies. Certainly one should consider the use of a wider range of ways of measuring it. Furthermore, the potential direction of research is the analysis of the reputational capital impact on the profitability of the investment processes in general and the value of portfolio companies in the short and long term. These studies would certainly allow for the making up of the present paucity of studies, especially empirical ones, in this field.

\section{Bibliography}

Arthurs J.D., Busenitz L.W., Hoskisson R.E., Johnson R.A. (2009), Signaling and initial public offerings: The use and impact of the lockup period, "Journal of Business Venturing", vol. 24, no. 4, pp. 360-372, http://dx.doi.org/10.1016/j.jbusvent.2008.02.004.

Asselain B., Mould R.F. (2010), Metodologia modelu proporcjonalnego ryzyka Coxa, "NOWOTWORY Journal of Oncology", vol. 60, no. 5, pp. 403-409.

Balicki A. (2006), Analiza przeżycia i tablice wymieralności, PWE, Warszawa.

Barry B., Muscarella C., Peavy J.W., Vetsuypens M.R. (1990), The Role of Venture capital in the Creation of Public Companies: Evidence from the Going-Public Process, "Journal of Financial Economics", vol. 27, issue 2, pp. 447-471, http://dx.doi.org/10.1016/0304-405X(90)90064-7. 
Bascha A., Walz U. (2001), Convertible Securities and Optimal Exit Decisions in Venture Capital Finance, "Journal of Corporate Finance", vol. 7, pp. 285-306, http://dx.doi.org/10.1016/ S0929-1199(01)00023-2.

Bienz C., Walz U. (2010), Venture capital exit rights, "Journal of Economics and Management Strategy", vol. 19, pp. 1071-1116, http://dx.doi.org/10.1111/j.1530-9134.2010.00278.x.

Black B.S., Gilson R.J. (1998), Venture capital and the structure of capital markets: Banks versus stock markets, "Journal of Financial Economics", vol. 47, pp. 243-277, doi:10.1016/S0304405X(97)00045-7.

Brav A., Geczy C., Gompers P.A. (2000), Is the abnormal return following equity issuances anomalous?, "Journal of Financial Economics", vol. 56, pp. 209-249, http://dx.doi.org/10.1016/S0304405X(00)00040-4.

Brav A., Gompers P. (1997), Myth or reality? The long-run underperformance of initial public offerings: evidence from venture- and non-venture-capital-backed companies, "Journal of Finance", vol. 52, pp. 1791-1821, http://dx.doi.org/10.1111/j.1540-6261.1997.tb02742.x.

Brav A., Gompers P. (2003), The Role of Lockups in Initial Public Offerings, "Review of Financial Studies", vol. 16, no. 1, pp. 1-29, http://dx.doi.org/10.1093/rfs/16.1.0001.

Cockburn I., MacGarvie M. (2009), Patents, thickets and the financing of early-stage firms: evidence from the software industry, "Journal of Economics and Management Strategy", vol. 18, pp. 729-773, http://dx.doi.org/10.1111/j.1530-9134.2009.00228.x.

Collet D. (2003), Modelling Survival Data in Medical Research, Chappman \& Hall/CR, New York, http://dx.doi.org/10.1007/978-1-4899-3115-3.

Cormier D., Ledoux M.-J., Magnan M., Aerts W. (2010), Corporate governance and information asymmetry between managers and investors, "Corporate Governance: The International Journal of Business in Society”, vol. 10, pp. 574-589, http://dx.doi.org/10.1108/14720701011085553.

Cumming D. (2008), Contracts and exits in venture capital finance, "Review of Financial Studies", vol. 21, pp. 1947-1982, http://dx.doi.org/10.1093/rfs/hhn072.

Cumming D.J., Johan S.A. (2009), Venture capital and Private equity Contracting. An International Perspective, Elsevier.

Cumming D.J., MacIntosh J.G. (2001), Venture Capital Investment Duration in Canada and the United States, "Journal of Multinational Financial Management", vol. 11, pp. 445-463, http:// dx.doi.org/10.1016/S1042-444X(01)00034-2.

Cumming D.J., MacIntosh J.G. (2003a), Venture-capital Exits in Canada and United States, "University of Toronto Law Journal", vol. 53, pp. 101-200, http://dx.doi.org/10.2307/3650880.

Cumming D.J., MacIntosh J.G. (2003b), A Cross-country Comparison of Full and Partial Venture Capital Exits, "Journal of Banking \& Finance", vol. 27, pp. 511-545, http://dx.doi.org/10.1016/ S0378-4266(02)00389-8.

Fendler W., Chałubińska J., Młynarski W. (2011), Techniki analizy przeżycia stosowane w onkologii-założenia, metodyka i typowe problemy interpretacyjne, "Onkologia w Praktyce Klinicznej", vol. 7, no. 2, pp. 89-101.

Fürth S., Rauch C. (2015), Fare Thee Well? An Analysis of Buyout Funds' Exit Strategies, "Financial Management", vol. 44, issue 4, pp. 811-849, http://dx.doi.org/10.1111/fima.12070.

Gompers P. (1996), Grandstanding in the venture capital industry, "Journal of Financial Economics", vol. 42, pp. 133-156, http://dx.doi.org/10.1016/0304-405X(96)00874-4.

Gompers P., Lerner J. (2006), The Venture Capital Cycle, MIT Press, Cambridge.

Hochberg Y.V. (2012), Venture Capital and Corporate Governance in the Newly Public Firm, "Review of Finance", vol. 16, pp. 429-480, http://dx.doi.org/10.1093/rof/rfr035.

Hochberg Y.V., Ljungqvist A., Lu Y. (2007), Whom You Know Matters: Venture Capital Networks and Investment Performance, "The Journal of Finance", vol. 62, no. 1, pp. 251-301, http:// www.jstor.org/stable/4123462. 
Hsu D.H. (2004), What Do Entrepreneurs Pay for Venture capital Affiliation?, "The Journal of Finance", vol. LIX, no. 4, pp. 1805-1844, http://dx.doi.org/10.1111/j.1540-6261.2004.00680.x.

Kaplan S., Martel F., Stromberg P. (2007), How do legal differences and experience affect financial contracts?, "Journal of Financial Intermediation", vol. 16, pp. 1-25, http://dx.doi.org/10.1016/j. jfi.2007.03.005.

Kaplan S., Stromberg P. (2003), Financial contracting theory meets the real world: an empirical analysis of venture capital contracts, "Review of Economic Studies", vol. 70, pp. 1-35, http:// dx.doi.org/10.1111/1467-937X.00245.

Klein J.P., Moeschberger M.L. (1997), Survival Analysis: Techniques for Censored and Truncated Data, Springer, New York, http://dx.doi.org/10.1007/978-1-4757-2728-9.

Krishnan C.N.V., Ivanov V .I., Masulis R.W., Singh A.K. (2011), Venture Capital Reputation, Post-IPO Performance, and Corporate Governance, "Journal of Financial and Quantitative Analysis", vol. 46, no. 5, pp. 1295-1333, http://dx.doi.org/10.1017/S0022109011000251.

Lin T., Smith R. (1998), Insider reputation and selling decisions: the unwinding of venture capital investments during equity IPOs, "Journal of Corporate Finance", vol. 4, pp. 241-263, http:// dx.doi.org/10.1016/S0929-1199(98)00005-4.

Lindsey L. (2002), The Venture Capital Keiretsu Effect: An Empirical Analysis of Strategic Alliances Among Portfolio Firms, SIEPR Discussion Paper No. 02-17, Stanford University, Stanford, California.

Liu X., Ritter J.R. (2011), Local underwriter oligopolies and IPO underpricing, "Journal of Financial Economics", vol. 102, pp. 579-601, http://dx.doi.org/10.1016/j.jfineco.2011.01.009.

Loughran T., Ritter J.R. (1995), The new issues puzzle, "The Journal of Finance", vol. L, no. 1, pp. 23-51, http://dx.doi.org/10.1111/j.1540-6261.1995.tb05166.x.

Masulis R.W., Thomas R.S. (2009), Does Private Equity Create Wealth? The Effects of Private Equity and Derivatives on Corporate Governance, "University of Chicago Law Review", vol. 76, pp. 219-260.

Megginson W.L., Weiss K.A. (1991), Venture capitalists certification in initial public offerings, "Journal of Finance", vol. 46, pp. 879-903, http://dx.doi.org/10.1111/j.1540-6261.1991. tb03770.x.

Nahata R. (2008), Venture capital reputation and investment performance, "Journal of Financial Economics", vol. 90, issue 2, pp. 127-151, http://dx.doi.org/10.1016/j.jfineco.2007.11.008.

Neus W., Walz U. (2005), Exit timing of venture capitalists in the course of an initial public offering, "Journal of Financial Intermediation", vol. 14, pp. 253-277, http://dx.doi.org/10.1016/j. jifi.2004.02.003.

Ortgiese J. (2007), Value Added by Venture Capital Firms, Josef Eul Verlag, Lohmar-Köln.

Paeglis I., Veeren P. (2013), Speed and consequences of venture capitalist post-IPO exit, "Journal of Corporate Finance", vol. 22, pp. 104-123, http://dx.doi.org/10.1016/j.jcorpfin.2013.04.005.

Panfil M. (2005), Fundusze private equity. Wpływ na wartość spółki, Difin, Warszawa.

Panfil M. (2009), Globalizacja inwestycji venture capital, [in:] A. Szablewski (ed.), Migracja kapitału w globalnej gospodarce, Difin, Warszawa.

Pietraszewski M. (2007), Proces inwestycyjny realizowany przez fundusze private equity, Wyższa Szkoła Humanistyczno-Ekonomiczna we Włocławku, Włocławek.

Povaly S. (2007), Private equity exits: Divestment process management for leveraged buyouts, Springer, Berlin-Heidelberg.

Puri M., Zarutskie R. (2012), On the lifecycle dynamics of venture-capital- and non-venture capital-financed firms, "Journal of Finance", vol. 67, pp. 2247-2293, http://dx.doi.org/10.2139/ ssrn.967841.

Ritter J.R. (1991), The Long-Run Performance of Initial Public Offerings, "Journal of Finance”, vol. XLVI, no. 1, pp. 3-27, http://dx.doi.org/10.1111/j.1540-6261.1991.tb03743.x. 
Rossa A. (2005), Metody estymacji rozkładu czasu trwania zjawisk dla danych cenzurowanych oraz ich zastosowania, Wydawnictwo Uniwersytetu Łódzkiego, Łódź.

Schmidt M., Bock C. (2015), Should I stay, or should I go? How fund dynamics influence venture capital exit decisions, "Review of Financial Economics", vol. 27, pp. 68-82, doi:10.1016/j. rfe.2015.09.002.

Schuster J.A. (2003), IPOs: Insights from Seven European Countries, Discussion Paper 461, Financial Markets Group, London School of Economics and Political Science, London.

Siwek P. (2005), Praktyka pierwszych ofert publicznych w Polsce, Wydawnictwa Fachowe CeDeWu.pl, Warszawa.

Sobańska K., Sieradzan P. (2004), Inwestycje private equity/venture capital, Key Text, Warszawa. Stevenson M. (2009), An Introduction to Survival Analysis, EpiCentre, IVABS, Massey University. Wrzesiński M. (2008), Kapitat podwyższonego ryzyka. Proces inwestycyjny i efektywność, Szkoła Główna Handlowa w Warszawie, Warszawa.

Zaremba-Pechmann L. (2010), Wykorzystanie modelu Coxa do oceny prawdopodobieństwa wyleczenia wirusowego zapalenia wątroby typu $C$, "Folia Pomeranae Universitatis Technologiae Stetinensis. Oeconomica", vol. 280, no. 59, pp. 123-128.

Zheng S.X. (2007), Are IPOs really overpriced?, "Journal of Empirical Finance”, vol. 14, pp. 287309, http://dx.doi.org/10.1016/j.jempfin.2006.06.001.

\section{Nadzór korporacyjny a czas realizacji pełnego wyjścia z inwestycji funduszy Private Equity na Giełdzie Papierów Wartościowych w Warszawie}

Streszczenie: W opracowaniu zaprezentowano rezultaty prac badawczych zorientowanych na poszukiwanie i ocenę zależności między przyjęciem określonych rozwiązań w zakresie ładu korporacyjnego w spółkach portfelowych funduszy private equity a czasem upływającym od wprowadzenia akcji spółki do publicznego obrotu po raz pierwszy do realizacji pełnego wyjścia z inwestycji przez fundusz. Wyniki badań wskazują, iż wyższemu udziałowi funduszy private equity w ogólnej liczbie głosów na walnym zgromadzeniu wspólników danej spółki przed przeprowadzeniem pierwszej oferty publicznej towarzyszy wydłużenie czasu realizacji pełnego wyjścia z inwestycji. Ponadto stosowanie konsorcjów inwestycyjnych, jak i wcześniejsze doświadczenie funduszu w realizacji dezinwestycji za pośrednictwem rynku giełdowego mogą być uznane za istotne predyktory hazardu realizacji całkowitego wyjścia z inwestycji. Badania empiryczne objęły 41 spółek portfelowych funduszy private equity, których akcje w procesie dezinwestycji zostały wprowadzone po raz pierwszy do publicznego obrotu na GPW w Warszawie w latach 2005-2015.

Słowa kluczowe: dezinwestycja, pierwsza oferta publiczna, IPO, fundusze private equity, pełne wyjście z inwestycji

JEL: G11; G24; G32

\begin{tabular}{|l|l|}
\hline \multirow{2}{*}{ OPEN ACCESS } & $\begin{array}{l}\text { C by the author, licensee Łódź University - Łódź University Press, Łódź, Poland. } \\
\text { This article is an open access article distributed under the terms and conditions } \\
\text { of the Creative Commons Attribution license C(-BY } \\
\text { (http://creativecommons.org/licenses/by/3.0/) }\end{array}$ \\
\cline { 2 - 2 } & Received: 2016-05-06; verified: 2016-10-21. Accepted: 2017-05-22 \\
\hline
\end{tabular}

